https://doi.org/10.18485/iipe_response2covid19.2021.ch16

\title{
RUSSIAN-CHINESE COOPERATION DURING THE COVID-19 CRISIS: MULTI-VECTOR AGENDA
}

\begin{abstract}
Yury V. Kulintsev ${ }^{1}$
Abstract: The article compares the actions of Russia and China in the first stage of the battle against COVID-19 and analyzes the approach of the two countries to international cooperation in the context of the crisis caused by the pandemic. The author aims to find out how the global COVID-19 crisis has affected Russian-Chinese cooperation and to identify positive and negative trends in bilateral relations between Moscow and Beijing in 2020.

COVID-19 has become a global challenge for the modern world order and all of humanity. From the very beginning of the outbreak, the international community has closely followed China's actions to counter the new coronavirus infection. Tough quarantine measures taken in China remain the most effective means of fighting the epidemic. The head of the WHO, T.Gebreyesus, admitted that if it was not for China's determination to carry out quarantine measures in Wuhan and other Chinese cities, then in the first months of the pandemic "there would be many more cases of disease and deaths from coronavirus in the world".

At the same time, China has faced unprecedented criticism and accusations from Washington for the emergence and spread of infection. The article analyzes the actions and statements of Beijing and Moscow, which were made by the two sides in order to prevent the transfer of the problem of combating coronavirus infection into the political plane. One illustrative example, in this case, is a comparison of the approaches of different
\end{abstract}

\footnotetext{
${ }^{1}$ Research Fellow, Institute of Far Eastern Studies of the Russian Academy of Sciences, Russia, kulintsev.y@ifes-ras.ru.
} 
countries to the allocation of limited resources, remedies, and plans for the use and provision of international access to the COVID-19 vaccine.

From the very beginning of the pandemic, Moscow and Beijing have been in close contact regarding the development of medicine against COVID-19. In August 2020, both states agreed to set up a joint laboratory to conduct coronavirus research. Such cooperation may be significant in the future, given that experts do not exclude the emergence of new global pandemics in the near future.

Keywords: COVID-19, international relations, Russia, China, geopolitics, humanitarian cooperation, vaccines

The new coronavirus infection has become a global challenge for all mankind and at the same time has demonstrated the approaches of various states to the development of international relations in crisis conditions when national health systems cannot cope with the flow of patients in need of help, and governments are forced to literally "pause" the economies of their countries.

In this context, the research interest is focused on big countries with large-scale geopolitical ambitions and on the steps they are taking. Those steps can be used by other participants in international society as guidelines or models for shaping their own foreign policy actions.

Russia and China have this kind of influence in the Eurasian space. Both countries are perceived on the world stage as geopolitical partners. Relations between them have reached a level close to that of allies. It has been repeatedly confirmed in speeches by high-ranking officials of the two countries, and it is also confirmed by the intentions of Moscow and Beijing to extend the Treaty of Good Neighborliness, Friendship and Alliance, which has been in force for 20 years (Zabrodina, 2021).

On January 30, 2020, the World Health Organization (WHO) declared the 2019nCov (the original name of the COVID-19 virus) epidemic as a public health emergency of international concern (Statement..., 2020). Tough quarantine measures taken in the regions of China most susceptible to infection have become the most effective means of fighting the epidemic. The head of the WHO, T. Gebreyesus, admitted that if it were not for China's determination to carry out quarantine measures in Wuhan and other cities in China, then "there would be more cases of disease and deaths from the coronavirus in the world" (WHO Director-General, 2020).

The outbreak of a new coronavirus infection, which was first detected in Wuhan at the end of December 2019, was stopped by the Chinese authorities by April 
thanks to a number of rather tough (especially at that time) government actions. The resources of almost the entire state were mobilized. At the same time, the high level of citizens' confidence in the state played an important role. The population supported and strictly adhered to quarantine measures and severe restrictions on mobility. It should be noted that at that time, only a small number of initial statistics on the incipient epidemic had been accumulated. China was forced to respond to the new virus, which was spreading at a rate much higher than the expectations of medical experts, without accurate data on the level of its lethality and infectiousness.

The article analyzes various aspects of bilateral interaction - political, economic, and humanitarian actions taken by the political leadership of the two countries in the context of the global COVID-19 crisis. It enables determining Moscow and Beijing's long-term intentions: to develop mutually beneficial cooperation or refute this intention.

The author adheres to the position that the COVID-19 pandemic is a classic example of events belonging to the "black swan" political category. It means that it is absolutely unpredictable and has a powerful impact on the subsequent development of international relations. In conditions of a real threat to national security, when there is no complete information about the virus and the degree of its influence on human life, the actions of the political leadership of various countries can be considered a reliable indicator that allows one to draw conclusions about the real state of affairs in relations between states.

\section{UNDER THE PRESSURE OF THE INTERNATIONAL ENVIRONMENT}

For China, the problem of combating COVID-19 has gone beyond the domestic agenda. Almost from the very beginning of the pandemic, Beijing was forced at the foreign policy level to protect its image from the aggressive rhetoric of Washington. The United States, led by then-President Donald Trump, tried to politicize the problem of coronavirus as much as possible, openly and (as was later confirmed) unproven accusing China of the infection, calling the virus a "Chinese" virus and calling for compensation from the PRC for the spread of coronavirus infection. The position of the Russian Federation on the accusations of China regarding the spread of COVID-19 was voiced by Russia's Permanent Representative to the UN V.Nebenzya, who expressed regret over the groundless accusations of the spread of coronavirus in the world.

Beijing has consistently denied the accusations at all levels. In June 2020, the Press Office of the State Council of the People's Republic of China published the White Paper "China's Actions to Combat COVID-19", the purpose of which was to 
inform the international community about China's efforts to combat the epidemic, share its experience in this area and explain its concept of a global response to the epidemic.

It is important to note here that already at the very beginning of the epidemic, the Chinese government took a fundamentally important position. It was decided to protect the lives and health of citizens even at the cost of a long-term economic downturn. The authorities were brave enough to introduce a complete quarantine in entire cities and even provinces.

In Russia, a number of political actions were taken in connection with the threat of the spread of an unknown infection. At the initial stage, they were negatively perceived in Beijing. In particular, on January 2, 2020, Russia already decided to strengthen sanitary control at the border with the PRC in the bordering Amur region. Later, control over the health conditions of all passengers arriving from the PRC in the Angara and Primorye regions was strengthened. At the end of January, flights from Wuhan to Moscow were cancelled, and flights to China were significantly limited (except for Aeroflot flights to Beijing, Shanghai, Guangzhou, and Hong Kong). Under an agreement with China, four more Chinese airlines operated flights to Moscow regularly. There was a separately allocated terminal $F$ for the arrival of flights from China in the main Russian airport "Sheremetyevo". The issuance of Russian electronic visas for Chinese citizens was suspended, and the sale of tours to China and the reception of tourist groups from China were suspended.

\section{BILATERAL HUMANITARIAN AID AND POLITICAL CONSULTATIONS}

At the same time, Russia became one of the first countries to provide humanitarian aid to China. Protective masks, an acute shortage of which was observed in China, were delivered to the PRC by aircraft of the Russian Ministry of Emergency Situations. It was the decision of the Operational Headquarters, which was organized in Moscow to control and prevent the import and spread of a new coronavirus infection in Russia. At the same time, all free stocks of medical masks were sent from Russia to China, which led to their temporary shortage, for example, in the pharmacy chains in Moscow.

On January 29, the development of a Russian test system for diagnosing COVID2019 was announced. The development of express tests was carried out by Russian virologists based on the genome of the new coronavirus COVID-2019, transferred by the Chinese side to Russian scientists. New express tests have made it possible to identify the coronavirus in the human body within two hours. From that moment, the joint work of scientists from the two countries was launched to develop a vaccine against COVID-19. 
Later, Chinese experts spoke extremely positively about the Russian test systems, which proved to be effective and had the advantage of being easier to use. In particular, the storage temperature of the Russian test system was plus 4 degrees, while the Chinese test system should have been stored at minus 20 degrees.

The above examples of bilateral cooperation became possible only thanks to the developed system of political interaction between Russia and China, which includes annual exchanges of official visits of heads of state, a mechanism for regular meetings of heads of government, the work of 5 joint intergovernmental commissions, which include more than 20 sub-commissions. The dialogue was constantly maintained during the pandemic, including a high-level dialogue. In particular, on February 1, telephone talks were held between Russian Foreign Minister Sergei Lavrov and his colleague Wang Yi when they discussed issues of Russian-Chinese cooperation in the fight against the spread of a new type of coronavirus infection. The Russian side gave a high assessment of the measures taken by China in the fight against the spread of the disease. The Chinese side thanked the Russian Federation for providing humanitarian assistance necessary to combat the spread of the epidemic.

In the following days, as part of the political agreements reached earlier, more than 4.5 thousand Russian tourists who were on Hainan Island as part of organized tour groups were evacuated to Russia. On February 4-5, 2020, by order of the President of the Russian Federation V.Putin, the evacuation of Russian citizens from the regions of China most affected by the coronavirus was carried out on aircraft of the Russian Aerospace Forces, accompanied by military doctors and specialists from the Russian Ministry of Defense. In total, 144 people were evacuated, including 128 Russian citizens and 16 CIS citizens, who were taken to a specialized centre in Tyumen for a two-week quarantine.

On behalf of the government of the Russian Federation, a delegation of six representatives of Rospotrebnadzor and the Ministry of Health of the Russian Federation arrived in Beijing on February 5, 2020. Epidemiological experts discussed topical issues regarding the spread of coronavirus infection and analyzed what additional measures could be taken to ensure the safety of citizens. In February 2020, on behalf of the government of the Russian Federation, the Russian Emergencies Ministry sent an II-76 transport aircraft with medicines and personal protective equipment to China. Humanitarian aid weighing more than 23 tons was formed by units of the Ministry of Emergency Situations from the Moscow, Tver and Voronezh regions, which became an example of the development of regional cooperation between Russia and China. It should be noted that the mechanism of "mutual assistance" applied at the state level made it possible to quickly establish 
channels for the supply of scarce goods and equipment to the most affected regions of China.

Political consultations between the two countries were also carried out in Moscow. The head of Rospotrebnadzor, A.Popova, met with the Ambassador of the People's Republic of China to the Russian Federation, Zhang Hanhui, following which the parties expressed their intention to continue cooperation in the anti-epidemic sphere, including in the field of disseminating information about coronavirus and methods of preventing the disease. The Russian side also noted that China had proven the effectiveness of its measures to combat COVID-19, and expressed its readiness to study the experience of the PRC in countering the spread of infection.

As a result of the agreements reached, new developments of Russian scientists from the Siberian Branch of the Russian Academy of Sciences were transferred to China. These include new test systems for quickly and efficiently determining the presence of the virus and several options for protective masks with unique characteristics. Russian scientists have also put forward a number of proposals for the accelerated development of new types of vaccines and therapeutic drugs based on antibodies from those who have been ill.

Starting from the end of March 2020, when the situation with COVID-19 in China was taken under control, the PRC government began to provide reciprocal humanitarian assistance to the Russian side. On March 23, 2020, as part of the implementation of the National Plan to Prevent the Import and Spread of a New Coronavirus Infection in the Russian Federation, 25.5 million protective masks were supplied to Russia from China. The deliveries were organized by the Russian Ministry of Industry and Trade with the assistance of the Russian Aerospace Forces. The supply of medical masks from China to the Russian Federation continued within the framework of regional cooperation. For example, the Heilongjiang provincial government, in response to a request from the Yakutia region of Russia, announced its readiness not only to send humanitarian aid, a batch of medical masks but also to establish the production of protective equipment on the spot. At the same time, earlier, in early February 2020, Yakutia delivered medical masks and medicines necessary during the epidemic to Heilongjiang. In the same period, 300 protective suits and 50 thousand disposable surgical masks were sent from Harbin, the Heilongjiang province to the Krasnoyarsk Territory. They were taken to Russia through the Heihe checkpoint. Emergency assistance was provided at the request of the government of the Krasnoyarsk Territory, which earlier donated 50,000 masks to the Heilongjiang Province to protect against coronavirus.

Certain actions by large Chinese businesses also indicate their desire to develop political dialogue with the Russian side. If the payments to AliExpress Russia in the amount of about $\$ 1.2$ million in compensation to Russian consumers for the delay 
of parcels from China are solely due to economic interests and the desire to maintain customer loyalty, then the provision of humanitarian aid by the founder of Alibaba to the Russian Ministry of Defense is a political step. The aircraft of the Russian Aerospace Forces delivered from China more than 1 million masks and 200 thousand test systems for detecting coronavirus infection, donated to the Ministry of Defense of the Russian Federation by the founder of Alibaba, Jack Ma. During a telephone conversation with the Minister of Defense of the Russian Federation, Jack Ma thanked Sergei Shoigu for the support provided by Russia to China during the development of the coronavirus pandemic and stressed that "he is helping Russia now and will continue this work as a sign of deep respect and friendly relations with the head of the Russian military department" (Jack Ma, 2020).

\section{RESPONSE TO COVID-19 WITH CHINESE CHARACTERISTICS}

By controlling the spread of infection, the Chinese government was able to avoid a long-term decline in economic performance. Since April 29, the PRC has moved from a state of "people's war" with COVID-19 to a regime of "prevention and control" of the disease and post-epidemic revival of the national economy. By the end of April, 99 per cent of major businesses and 88 per cent of the medium, small, and micro-businesses had resumed operations.

It should be noted that during the coronavirus epidemic in the first quarter, China's GDP fell by $6.8 \%$, but in the second quarter, it grew by $3.2 \%$. In the third quarter, it grew by $4.9 \%$, and in the fourth, it grew by by $6.5 \%$. The economic growth rate reached $2.3 \%$ at the end of 2020 . The PRC became the only large economy in the world that showed growth in a difficult year of the pandemic.

An analysis of the efforts made by the Chinese government reveals several factors that have become decisive in the fight against the COVID-19 epidemic. First, it is the determination of the PRC leadership to adopt extreme quarantine measures for the 11-million metropolis. The strict restrictions on the social contacts of citizens made it possible to gain time (for the world community as well) and prevent the uncontrolled spread of a new viral infection in the first months of the epidemic.

Second, the mobilization of resources across the country helped to cope with the crisis in Wuhan. The central government of the PRC has clearly stated its position: "The continuous supply of the necessary resources to control the epidemic in the Hubei Province and Wuhan City are becoming one of the national priorities." The PRC government ensured the delivery of the required resources, and the Hubei provincial administration was responsible for their use and internal distribution. The timely mobilization and dispatch of specialized medical personnel to Hubei province also played a decisive role. 
Thirdly, the experience of the mechanism of "mutual assistance" widely used at the state level made it possible to establish channels of assistance to the cities of the Hubei province in the shortest possible time. The principle of operation of this mechanism implies that in the event of a crisis situation in one of the provinces, the central government of the PRC obliges one of the neighbouring provinces, less affected by the crisis, to provide assistance to one of the cities in the affected region. In particular, immediately after the outbreak of the COVID-19 epidemic in Hubei, the PRC government ordered 16 other Chinese provinces to help the cities of Hubei province. Thus, the Shandong province provided assistance to Huanggang city and the Jiangsu province to Xiaogang city. A similar self-help mechanism has been used for years in China to combat poverty, with wealthy provinces in the southeastern region pledging to help cities in poorer regions of northern and southwestern China. The same scheme was applied after the earthquake in the Sichuan province in 2008, which made it possible to cope with the consequences of the disaster within three years.

Fourth, the implementation of the three-level quarantine system, along with the creation of the necessary medical infrastructure within the Hubei province, avoided high mortality rates and shortened the spread of the epidemic in the country.

Fifth, the ongoing information campaign to work with public opinion made it possible to avoid the critical spread of panic in the country. Providing extensive data on the course of the epidemic and informing the public about all aspects of the new viral infection has significantly raised the awareness of the population and also contributed to the improvement of the level of personal hygiene of citizens.

Sixth, the use of psychological measures made it possible to tune the population to constructive interaction with the state. In particular, the active demonstration in the media of the state's efforts to normalize the situation, the formation of a heroic attitude towards medical specialists working in Wuhan, the environment with a high level of patient care, the construction of new modern hospitals with comfortable wards and the provision of high-quality food, the use of hotels and sanatoriums for quarantining patients with an unconfirmed diagnosis, all contributed to a decrease in the general level of anxiety and increased the willingness of the population to undergo quarantine or voluntarily go for treatment.

Seventh, the Chinese government notes the significant contribution of Internet companies in the fight against the spread of the epidemic. Chinese IT giants Tencent, Alibaba, Baidu, ZTE, iFLYTEK and JD.com have provided their technologies for processing and using arrays of big data, artificial intelligence and communications of the 5 th generation $(5 \mathrm{G}$ ) standard for remote monitoring, diagnosis and provision of medical, information and service services.

Eighth, China has made efforts to keep the economy stable. Even with harsh quarantine measures that largely restricted population flows and private and public 
companies, China kept open the supply channels for materials needed to fight the epidemic in the Hubei province and ensure an acceptable standard of living for the rest of the population.

At the state level, a number of measures were taken to provide financial support to small and medium-sized businesses, including the provision of a deferral for rent payments, the provision of targeted assistance to companies on the verge of bankruptcy. Seasonal workers were given the opportunity to return to production after the New Year's holidays on specially organized trains and buses. The measures taken made it possible to maintain the industrial base of China in working conditions. According to reports from relevant statistic departments, starting from the second half of March 2020, almost all large companies in the PRC resumed their work.

The actions of the Chinese government show that the adoption of a specific set of multi-tiered measures can successfully stop the spread of the COVID-19 epidemic (Kulintsev, 2020). In the case of China, at the state level, decisions were made: to increase the duration of the general New Year holidays, which made it possible to reduce the level of social contacts; to use the medical resource base on a national scale, which made it possible to provide the regions most affected by the epidemic with the necessary materials. At the provincial level, local governments have closed access to public places (theatres, restaurants, shopping and entertainment centres) and opened new or repurposed existing hospitals to increase the ability to provide specialized medical care to patients with a confirmed diagnosis of COVID-19. On a personal level, a request for information on movements in the previous two weeks was implemented, which made it possible to identify persons who could potentially come into contact with the carrier of the infection and send them to a 14-day self-isolation.

On August 17, 2020, the State Intellectual Property Office of the People's Republic of China issued a patent for the Ad5-nCoV vaccine developed in China, which was created by CanSino Biologics in conjunction with the PLA Academy of Military Medical Sciences.

China patented its coronavirus vaccine a week after Russia. But in fact, Beijing began testing the vaccine earlier than Moscow but did not dare to register it until the third phase of clinical trials was completed. That is the stage of mass tests of the effectiveness and harmlessness of the drug in the general population. Since the rules for the registration of vaccines at the international level are not officially formalized anywhere, Russia, based on the available experience, registered Sputnik $\mathrm{V}$ after phase II, that is, after testing on groups of young, healthy, physically strong volunteers. Phase III was combined with the beginning of mass vaccination.

Formally, the Chinese side congratulated Moscow. However, realizing the potential economic dividends from vaccine exports, Beijing followed Russia's 
example and also registered its vaccine. By September 2020, Sinovac and the Sinopharm pharmaceutical group have also announced their fast-track vaccine registrations for emergency use.

\section{RUSSIAN-CHINESE MULTILATERAL COOPERATION IN THE NEW CONDITIONS}

Another feature of the period under review was the transfer of most bilateral and multilateral international events to the online format. For example, the 7th Russian-Chinese EXPO was postponed to July 2021 due to an unfavourable epidemic situation. The exhibition was to be held from 7 to 10 July 2020 in Yekaterinburg. In 2021, ESCPO will be held simultaneously with the Innoprom international industrial exhibition. The Forum of Young Diplomats of the BRICS Countries, which was to be held in Kazan, was postponed to a later date.

The SCO and BRICS summits, which were to be held under the chairmanship of Russia in St. Petersburg, were postponed to a later date. Ultimately, both summits were held online, relying on the world experience of holding high-level international meetings. One of the first events of this kind on a global scale was the April videoconference on coronavirus by the heads of the Ministries of Health of the G20 countries, during which the impact of COVID-19 on society and the health sector, as well as the problems of ensuring the availability of medical services for the population were discussed. After that, online meetings of senior BRICS officials, online meetings of SCO experts, a video conference of the foreign ministers of the RIC countries, a video conference of the foreign ministers of the $\mathrm{G} 20$ countries and the final summit of the G20 online summit were held.

The activities of Russia and China within the SCO as an international organization, in which they are the main drivers of development, were characterized by the intensification of the number of contacts and the expansion of the agenda under discussion. It was the SCO that began to be used as a platform for launching and testing the mechanism of operation of multilateral international videoconferences. In particular, the first online meeting was a meeting of experts on the preparation of the Meeting of Ministers of Health of the SCO member states. After that, several dozen meetings with the participation of representatives of the SCO Secretariat took place in the format of videoconferences within the SCO, including a seminar of the SCO Interbank Consortium; SCO round table on the transition to mutual settlements in national currencies; videoconference on SCO regional cooperation; videoconference on the impact of the coronavirus pandemic on interaction within the SCO; expert meeting on the preparation of the SCO Startup Forum; videoconference "The Role of Russia in the Development of the SCO"; Online seminar on cooperation in environmental protection within the SCO; 5 th 
International Youth Conference "Model SCO"; 1st Meeting of the SCO Economic Analytical Centers Consortium; SCO videoconference on the impact of the COVID19 pandemic on the development of the global economy; SCO seminar on modern technologies in the field of drug prevention; online consultations of experts and heads of services of the SCO states on sanitary and epidemiological well-being; business conclave of the SCO.

One of the first online events with the participation of high-ranking officials was a video conference of the SCO foreign ministers held in May 2020. After that, the practice of holding such online meetings began to be actively used in the framework of political interaction among the SCO member states. In the second half of 2020, the following took place online:

- The 15th Meeting of the Secretaries of the Security Councils of the SCO States;

- The meeting of the President of the Russian Federation with the Foreign Ministers of the SCO countries;

- The meeting of the Council of Ministers of Foreign Affairs of the SCO States;

- The 7th Meeting of the Ministers of Justice of the SCO States;

- The 18th Meeting of Prosecutors General of the SCO countries;

- The 5th Meeting of the Ministers of Agriculture of the SCO countries;

- The 19th Meeting of Ministers for Foreign Economic Activity of the SCO States;

- The 8th Meeting of the SCO Ministers of Transport;

- The 15th Meeting of the Chief Justice of the Supreme Courts of the SCO States;

- The 10th Meeting of the Heads of the Competent Authorities of the SCO States on Combating Illicit Drug Trafficking;

- The 1st Forum of Heads of Regions of the SCO States;

- The 16th Meeting of the SCO Interbank Consortium Council;

- The 15th Meeting of the SCO Forum;

- The 1st Interparty Forum "SCO +";

- The 13th meeting of the SCO Youth Council;

- The 20th SCO Summit;

- The 19th Meeting of the SCO Heads of Government Council (Shanghai Cooperation Organization, 2020).

The SCO's functionality and its rapid adaptation to working in new conditions also serve as a manifestation of the joint political efforts of Moscow and Beijing. In addition, it was within the framework of the SCO that both countries began to discuss and develop solutions to counter the main challenge of 2020 - the COVID- 
19 pandemic. In July 2020, the SCO issued a document: "An Overview of Advanced Measures Taken by the SCO Countries to Counter the Spread of COVID-19" that could be applied globally (The member states..., 2020).

The decision to begin joint work by Russia's and China's leading virology centres to develop a vaccine against the virus should also be viewed as a political step. In August 2020, within the framework of the Years of Chinese-Russian Scientific, Technical and Innovative Cooperation, the Russian Research Institute of Vaccines and Serums named after I. Mechnikov and the Chinese Institute of Microbiology of the CAS signed a memorandum on the creation of a joint laboratory for COVID2019 research.

Political interaction between Russia and China in the international arena during the period under review retained continuity and was distinguished by mutual support on the main issues of the global and regional agenda.

In particular, in the UN Security Council, the Russian Federation and the PRC came out with a common position on the Western draft resolution on humanitarian aid in Syria; Moscow and Beijing hold similar positions in the framework of the quadrilateral consultations on a settlement in Afghanistan; on China's participation in the START-3 treaty; to ban the deployment of weapons in space. Both countries reaffirmed their adherence to the principle of non-interference in the internal affairs of another state regarding the situations in Hong Kong, on the Sino-Indian border, as well as on performances in Belarus.

Political solidarity was shown by Russia and China regarding the statements of the United States on Hong Kong, against accusations of the spread of COVID-19, as well as regarding the charges against the Russian Federation and the PRC of cyberattacks.

An illustrative example of political interaction between Moscow and Beijing should be considered a joint article by the ambassadors of the Russian Federation and China to the United States, published on the occasion of the 75th anniversary of the Second World War victory in one of the leading American magazines, "Defense One." The article expressed a warning to the international community about the inadmissibility of rewriting history. It also became a call for the United States to abandon the thinking of the Cold War era.

\section{CONCLUSIONS}

The political interaction between Russia and China in the context of the COVID19 pandemic developed in several directions and had a number of features. The multi-vector agenda of the discussed issues was retained; a mechanism has been 
developed to allow major political events to be held online; breakthrough results were achieved in certain areas of bilateral cooperation, in particular, in the field of joint work to counter the COVID-19 pandemic, providing mutual humanitarian assistance, stimulating the development of interregional cooperation, but the greatest dynamics was shown by the interaction of medical departments in the development of test systems, vaccines, and exchange of medical experience.

Certain elements of the competition were observed during the registration of the vaccine and the introduction of restrictive measures against entry into each other's territory. At the same time, at the global level and in multilateral formats, Russia and China have demonstrated similar positions on major international issues. The results of the first meeting of the foreign ministers of the Russian Federation and the PRC after the start of the pandemic, held in April 2021 in person, confirmed that both countries successfully passed the crisis period, showing a high level of mutual trust. The actions of the political leadership of the two countries in the context of the COVID-19 pandemic confirmed the sincerity of the intentions of Moscow and Beijing to develop long-term and mutually beneficial cooperation.

\section{REFERENCES}

ДжекМаподарилМинобороныРФболее 1 млнмедицинскихмасок [Jack Ma donated more than 1 million medical masks to the Russian Defense Ministry].(2020, March 26), retrieved fromhttps://tass.ru/obschestvo/8085301. Accessed 10 July, 2021. (In Russian).

Bargués, P. (2020, March 23). Containing coronavirus: resilience in times of catastrophe, retrieved from https://www.e-ir.info/2020/03/23/containingcoronavirus-resilience-in-times-of-catastrophe/. Accessed 16 August2021.

Furedi, F. (2020, March 20). A Disaster without Precedent,retrieved from https:// www.spiked-online.com/2020/03/20/a-disaster-without-precedent/. Accessed 16 August 2021.

Harari, Y. N. (2020, March 20). The World after Coronavirus, retrievedfrom https:// www.ft.com/content/19d90308-6858-11ea-a3c9-1fe6fedcca75?fbclid= IwAR3J79luulcOq2bnthqQcQ8mWIJc1sj8y0GEeWBr3U_oy-dXQbH60vfgVd8. Accessed 16 August 2021.

Kothari, A. (2020, March 27). Coronavirus and the Crisis of the Anthropocene, retrieved from https://theecologist.org/2020/mar/27/coronavirus-and-crisisanthropocene. Accessed 16 August 2021.

Kulintsev,Y.V. (2020, April 02). Опыт Китая в борьбе с эпидемией COVID-19: хронологиясобытий и предпринимаемыемеры [China's Experience in 
Fighting COVID-19: Timeline and Action], retrieved from https://russian council.ru/analytics-and-comments/analytics/opyt-kitaya-v-borbe-s-epidemieycovid-19-khronologiya-sobytiy-i-predprinimaemye-mery/. Accessed 10 July 2021. (InRussian).

Runciman, D. (2020, March 27). Coronavirus has not suspended politics - it has revealed the nature of power, retrieved from https://www.theguardian.com/ commentisfree/2020/mar/27/coronavirus-politics-lockdown-hobbes. Accessed 16 August 2021.

Shanghai Cooperation Organization Secretariat (2020). News reports, retrieved from http://eng.sectsco.org/news/. Accessed 10 July 2021.

Statement on the second meeting of the International Health Regulations (2005) Emergency Committee regarding the outbreak of novel coronavirus (2019nCoV). (2020, January 30), retrieved from https://www.who.int/news/item/3001-2020-statement-on-the-second-meeting-of-the-international-health-regulat ions-(2005)-emergency-committee-regarding-the-outbreak-of-novelcoronavirus-(2019-ncov). Accessed 10 July 2021.

The member states of the SCO measures taken in the field of healthcare to counter the spread of the novel coronavirus (COVID-19). (2020, September 18) retrieved from http://eng.sectsco.org/news/20200918/677732.html. Accessed 10 July 2021.

WHO.Global research on coronavirus disease (COVID-19) (2020), retrieved from https://www.who.int/emergencies/diseases/novel-coronavirus-2019/globalresearch-on-novel-coronavirus-2019-ncov. Accessed 13 August 2021.

WHO Director-General's statement on IHR Emergency Committee on Novel Coronavirus (2019-nCoV). (2020, January 30), retrieved from https://www.who. int/director-general/speeches/detail/who-director-general-s-statement-on-ihremergency-committee-on-novel-coronavirus-(2019-ncov). Accessed 10 July 2021.

Zabrodina, E. (2021, March 23). Россияи Китайпродлили Договоро добро соседствеи дружбе напятьлет [Russia and China extend the Treaty of Good Neighborliness and Friendship for five years], retrieved from https://rg.ru/ 2021/03/23/rossiia-i-kitaj-prodlili-dogovor-o-dobrososedstve-i-druzhbe-na-piatlet.html. Accessed 20 May 2021. 